\title{
KOMUNIKASI KEBIJAKAN BANTUAN PANGAN NONTUNAI MELALUI E-WARONG
}

\author{
Engkus \\ Fakultas Ilmu Sosial dan Ilmu Politik, Jurusan Administrasi Publik \\ Universitas Islam Negeri Sunan Gunung Djati Bandung \\ Jl. A.H. Nasution 105 Bandung, Jawa Barat, 40614, Indonesia \\ No. Telp./HP: 082216266677 \\ E-mail: engkus@uinsgd.ac.id
}

Naskah diterima pada tanggal 3 Oktober 2019, direvisi tanggal 25 Februari 2020, disetujui tanggal 16 Maret 2020

\section{COMMUNICATION OF NON-CASH FOOD ASSISTANCE POLICY THROUGH E-WARONG}

\begin{abstract}
The main problem of this research is the communication of central government policy at the village level with beneficiary families (KPM), which is not yet running optimally. The factors causing this were communication, resources, disposition (attitude of the implementer), and bureaucratic structure. This study aims to find out how the implementation of central government policy communication in the form of non-cash assistance at the lowest level in the kelurahan. Also, to find out the E-Warong program that is expected to be targeted to beneficiary families, so poverty is reduced. This research used a descriptive qualitative method. Data collection techniques are done through interviews, observation, and documentation studies. The results showed that policy communication had not run optimally. We recommend policy communication through advocacy and supervision. It is expected that in the future, there will be accurate, valid, and reliable KPM data.
\end{abstract}

Keywords: public policy communication, E-Warong, non-cash food aid.

\begin{abstract}
Abstrak. Masalah utama dari penelitian ini adalah komunikasi kebijakan pemerintah pusat di level kelurahan dengan Keluarga Penerima Manfaat (KPM) yang belum berjalan optimal. Faktor yang menyebabkan yaitu komunikasi, sumber daya, disposisi (sikap implementer) dan struktur birokrasi. Tujuan penelitian ini adalah untuk mengetahui bagaimana implementasi komunikasi kebijakan pemerintah pusat berupa bantuan nontunai di level terendah di kelurahan. Juga untuk mengetahui apakah program E-Warong diberikan tepat sasaran pada Keluarga Penerima Manfaat sehingga kemiskinan berkurang. Penelitian ini menggunakan metode kualitatif deskriptif. Teknik pengumpulan data melalui wawancara, dan studi dokumentasi. Hasil penelitian ini menunjukkan bahwa komunikasi kebijakan belum berjalan secara optimal. Kami merekomendasikan agar terjalin komunikasi kebijakan melalui advokasi dan pengawasan. Diharapkan di masa mendatang terdapat data KPM yang akurat, sah, dan dapat dipercaya.
\end{abstract}

Kata kunci: komunikasi kebijakan publik, E-Warong, bantuan pangan nontunai.

\section{PENDAHULUAN}

Undang-Undang Dasar 1945 mengamanatkan bahwa fakir miskin dan anak-anak yang terlantar dipelihara oleh negara, dan tiap-tiap warga negara berhak atas pekerjaan dan penghidupan yang layak bagi kemanusiaan, kemudian pemerintah mengeluarkan peraturan-peraturan yang berkenaan dengan penanggulangan kemiskinan dalam berbagai bidang. Namun di Indonesia saat ini pada kenyataannya kemiskinan dan kerentangan pangan masih menjadi tantangan bagi pemerintah. Kemiskinan disebabkan oleh beberapa faktor salah satunya adalah sumber daya manusia 
yang kurang memadai atau disebabkan karena sikap berdiam diri, enggan atau tidak dapat berusaha. Tingkat kemiskinan rumah tangga dapat digambarkan dengan pendapatan dan pola pengeluarannya. Pendapatan yang rendah menyebabkan daya beli juga rendah sehingga rumah tangga miskin melakukan pilihan dalam membelanjakan penghasilannya bahkan mungkin harus meniadakan beberapa kebutuhan dasar lainnya untuk memenuhi kebutuhan dasar tertentu.

Menurut Badan Pusat Statistik (2016) kriteria keluarga miskin jika berdasarkan pendekatan dasar keinginan (basic needs), adalah ketidakmampuan seseorang untuk memenuhi kebutuhan makanan maupun non makanan yang bersifat mendasar. Batas kecukupan pangan dihitung dari besarnya rupiah yang dikeluarkan untuk kebutuhan makanan dan energi minimal yang dikelurkan 2.100 kalori perkapita perharinya. Batas kecukupan nonpangan dihitung dari besarnya rupiah yang dikeluarkan seperti: perumahan, sandang, kesehatan, pendidikan, transportasi, dan lain-lain.

Salah satu kebijakan oleh pemerintah untuk pengentasan kemiskinan terutama dalam pemenuhan kebutuhan pokok adalah Program Bantuan Pangan Nontunai (BPNT) berlandaskan pada Peraturan Presiden Republik Indonesia Nomor 63 Tahun 2017 tentang Penyaluran Bantuan Sosial Nontunai (BPNT-KEMENSOSRI, 2018).

Dalam Pedoman Umum BPNT (2018) disebutkan bahwa bantuan sosial pangan yang disalurkan dalam bentuk nontunai dari pemerintah kepada KPM setiap bulannya, melalui mekanisme uang elektronik yang digunakan hanya untuk membeli bahan pangan di pedagang bahan pangan atau disebut E-Warong yang telah bekerjasama dengan bank penyalur. Berdasarkan hasil observasi di Kelurahan Cipadung Kulon tahun 2019 ditemukan bahwa penyaluran BPNT mengalami beberapa kendala di antaranya belum tepatnya sasaran. Masih banyak masyarakat yang mampu mendapatkan bantuan sedangkan yang benarbenar tidak mampu sama sekali tidak terdata dalam penerima bantuan program ini, tetapi yang sudah pindah ataupun meninggal masih mendapatkan bantuan. Hasil observasi juga menemukan keterlambatan pembuatan Kelompok Keluarga Sasaran (KKS) para KPM, dan masih ada masyarakat yang tidak bisa mencairkan BPNT karena saldo di kartu KPM nol dari yang seharusnya masuk sebesar Rp110.000,00 perbulan, dan ada yang hanya mendapat satu kali bantuan saja, juga terjadi keterlambatan penetapan E-Warong/agen sebagai sarana penyaluran bahan pangan.

Tujuan dan hasil penelitian ini diharapkan bermanfaat untuk masukan dan koreksi bagi pemerintah, khususnya aparatur di Kelurahan Cipadung Kulon, agar mampu melaksanakan kebijakan Program BPNT secara optimal.

\section{LANDASAN KONSEP}

\section{Kajian Penelitian Sejenis}

Penelitian sejenis yang berkaitan dengan komunikasi kebijakan publik adalah Pengelolaan Pedagang Kaki Lima Berbasis Pada Kearifan Lokal (Kajian Pengelolaan Pedagang Kaki Lima di Kota Surakarta). Metode penelitian yang digunakan dalam penelitian tersebut adalah metode kualitatif deskriptif. Teknik yang digunakan adalah wawancara, observasi dan dokumentasi. Hasil penelitian komunikasi kebijakan membantu menemukan norma dan harmonisasi baru dalam implementasi kebijakan yakni memanusiakan manusia. Komunikasi kebijakan juga membantu pelaksana dan target kebijakan untuk bekerja sama dalam mencapai tujuan kebijakan. Kearifan lokal sebagai dasar mengorganisasi dan memesan pedagang informal berdasarkan pendekatan sosial-budaya, berpusat pada karakteristik nguwongke-uwong; di mana manusia dihargai, saling menghormati, saling membantu untuk menciptakan kebersamaan dan keseimbangan. Kearifan lokal selalu berinvestasi dan mewujudkan komunalitas, musyawarah, dialog, dan komunikasi dua arah. Oleh karena itu dalam organisasi pedagang informal di Surakarta, kerukunan diwujudkan melalui budaya organisasi pedagang informal (Nurati, 2016). Kajian yang peneliti lakukan berbasis komunikasi antara pemerintah pusat, kelurahan dan 
masyarakat (bureaucrat and citizen based communication), di mana fenomena yang terjadi komunikasi pemerintah pusat (top level bureaucrats), dan pemerintah kelurahan serta masyarakatnya, sehingga komunikasi kebijakan pusat dapat dilihat secara jelas proses dan hasilnya pada tataran implementasi di level kelurahan (street level bureaucrats).

\section{E-Warong dan Program Bantuan Pangan Nontunai}

Untuk mendukung penyaluran program BPNT, maka Kementerian Sosial mengeluarkan program E-Warong (Warung Gotong Royong Elektronik) sebagai sarana dalam penyaluran bantuan sosial secara nontunai. Salah satu E-Warong yang telah beroperasi adalah E-Warong Yani di Kelurahan Cipadung Kulon Kecamatan Panyileukan Kota Bandung, yang bertujuan untuk mengoptimalkan penyaluran bantuan program BPNT.

Implementasi Program E-Warong ini, Kementerian Sosial RI melibatkan beberapa unsur terkait seperti perbankan, Perum Bulog serta masyarakat Program Keluarga Harapan (PKH) yang tidak hanya sebagai objek, namun juga sebagai pelaku E-Warong. Program E-Warong ini secara khusus diluncurkan agar distribusi bantuan pemerintah tepat kualitas, kuantitas, dan sasaran (Yusnita, Duwi Agustina, 2017)

Teknologi dalam komunikasi yang kerap digunakan pada E-Warong adalah Mesin Electronic Data Capture (EDC) yang merupakan sebuah mesin khusus yang dibuat untuk memudahkan nasabah dalam melakukan transaksi pembayaran. Biasanya mesin EDC tersedia di minimarket, supermarket, SPBU, ATM (nontunai) dan sebagainya. Sehingga nasabah dapat melakukan pembayaran menggunakan kartu ATM (nontunai). Mesin EDC berbentuk seperti ponsel jadul yaitu hanya tersedia layar yang kecil seperti kalkulator dan tombol input angka seperti ponsel. Di bagian samping terdapat lubang khusus sebagai tempat untuk menggesek kartu ATM/kartu debit, sedangkan di bagian bawah terdapat sensor chip untuk kartu debit yang menggunakan chip (Mulyana, 2018).

\section{Komunikasi Kebijakan Publik}

Pada era modern sekarang ini program apapun yang berdimensi pelayanan masyarakat dituntut untuk berkualitas. Suparman (2017) menyebutkan bahwa pelayanan publik sejatinya diharapkan oleh masyarakat pengguna layanan dalam bentuk dan pengantaran yang prima dalam arti pelayanan yang mudah, cepat, tepat, dan aman ditandai oleh pelayanan yang tidak berbelit-belit, pelayanan yang well-informed, responsive, accomodative, consistent, dan adanya kepastian (waktu, biaya, hukum) dan tidak dijumpai pungutan tidak resmi. Itulah di antaranya penerapan prinsip pelayanan prima dalam metode dan prosedur yang erat dengan kebijakan publik (public policy).

Implementasi kebijakan sesungguhnya bukanlah sekedar bersangkut paut dengan mekanisme penjabaran keputusan-keputusan politik ke dalam prosedur-prosedur rutin lewat saluran-saluran birokrasi, melainkan lebih dari itu, ia menyangkut masalah konflik, keputusan dan siapa yang memperoleh apa dari suatu kebijaksanaan Grindle dalam Wahab (2014). Oleh sebab itu tidak terlalu salah jika dikatakan implementasi kebijaksanaan merupakan aspek yang penting dari keseluruhan proses kebijaksanaan (Wahab, 2014)

Ripley dan Franklin dalam Winarno, (2014) berpendapat bahwa implementasi adalah apa yang terjadi setelah undangundang diterapkan yang memberikan otoritas program, kebijakan, keuntungan (benefit), atau suatu jenis keluaran yang nyata (tangible output). Widodo dalam Kusumadewi (2016) menyatakan "Implementasi merupakan proses yang melibatkan sejumlah sumber yang termasuk manusia, dana, dan kemampuan organisasional yang dilakukan oleh pemerintah maupun swasta (individu atau kelompok). Proses tersebut dilakukan untuk mencapai tujuan yang telah ditetapkan sebelumnya oleh pembuat kebijakan".

Syafri (2010) menyatakan bahwa model implementasi kebijakan ini, keberhasilannya sangat ditentukan beberapa faktor penting. Edward III dalam Pasolong (2013), menyatakan bahwa faktor-faktor tersebut: (1) komunikasi; (2) sumber daya; (3) sikap implementer (dispositions); dan (4) struktur 
birokrasi. Faktor-faktor tersebut dapat dijelaskan sebagai berikut:

- Komunikasi, persyaratan pertama bagi efektivitas implementasi kebijakan adalah para pelaksana harus mengetahui apa yang seharusnya mereka lakukan, sebab hanya dengan cara demikian proses komunikasi antarsesamanya akan dapat berjalan dengan baik. Dalam proses komunikasi terkandung transmisi, konsistensi, dan kejelasan (clarity).

- Sumber daya, yang akan mendukung implementasi kebijakan yang efektif di sini menyangkut: staf, wewenang, informasi, dan fasilitas-fasilitas.

- Disposisi, juga menyangkut persepsi, kewenangan, pemahaman dan komitmen para pelaksana (implementer) untuk menetapkan suatu kebijakan. Terdapat tiga kemungkinan sikap dari disposisi yaitu menerima, menolak atau bersikap netral.

- Struktur birokrasi, secara umum birokrasi merupakan suatu badan yang paling sering terlibat dalam implementasi kebijakan secara keseluruhan. Bentuk organisasi dipilih sebagai suatu kesepakatan kolektif untuk memecahkan berbagai masalah sosial. Struktur organisasi-organisasi pelaksana kebijakan mempunyai pengaruh penting pada impelentasi kebijakan. Para pelaksana kebijakan dapat saja mengetahui apa yang harus dilakukan. Komunikasi dilakukan harus akurat dan mudah dimengerti oleh para pelaksana kebijakan, tetapi jika para pelaksana kebijakan kurang sumbersumber, maka implementasi kebijakan tersebut cenderung tidak efektif dan efesien.

\section{METODE PENELITIAN}

Metode yang digunakan dalam penelitian ini adalah metode kualitatif, dan penelitian untuk masalah-masalah yang aktual yang sedang terjadi dalam kehidupan masyarakat, Singarimbun dalam (Engkus E, 2018). Teknik pengumpulan data yang digunakan adalah teknik observasi, wawancara dan studi dokumentasi. Teknik observasi digunakan untuk memastikan keadaan yang sebenarnya di lapangan. Teknik wawancara digunakan untuk memperoleh data yang mendalam dari informan yang terdiri dari sembilan orang yang terdiri dari Kantor Kelurahan Cipadung Kulon, Garda tahun 2017, lima orang masyarakat penerima manfaat, lihat Tabel 1. Teknik studi pustaka digunakan untuk memperoleh dokumen mengenai program bantuan pangan nontunai. Dengan penelaahan dokumentasi, peneliti bermaksud menelaah realisasi pembangunan nasional sebagaimana digariskan dalam Rencana Pembangunan Nasional (RPN) di tingkat pelaksana, (Engkus, 2017).

Teknik analisis data menggunakan teori Miles \& Huberman dalam (Silalahi, 2009), analisis tersebut terdiri dari tiga tahapan yang terjadi secara bersamaan, yaitu:

- Data Reduksi.

Reduksi data diartikan sebagai proses pemilihan, pemusatan perhatian pada penyederhanaan, pengabstraksian, dan transformasi data kasar yang muncul dari cacatan cacatan peneliti di lapangan. Reduksi data merupakan suatu bentuk analisis yang menajamkan, menggolongkan, mengarahkan, membuang yang tidak perlu, dan mengorganisasi data sedemikian rupa sehingga simpulannya dapat ditarik serta diverifikasi.

- Penyajian Data

Paparan data atau penyajian data yaitu sebagai sekumpulan informasi tersusun, dan memberikan kemungkinan adanya penarikan simpulan dan pengambilan tindakan.

- Penarikan Simpulan atau Verifikasi

Penarikan simpulan dan verifikasi yaitu temuan yang dapat berupa deskripsi atau gambaran sesuai objek yang bersifat sementara dan akan berkembang yang setelah itu akan menjadi lebih jelas, dapat berupa hubungan kausal atau interaktif, hipotesis/proposisi atau teori. 


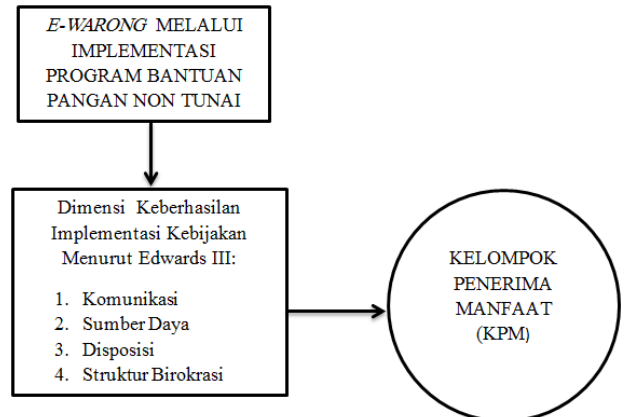

Sumber: Edward III dalam Pasolong (2013), (diolah Peneliti).

Gambar 1. Kerangka Konseptual

Tabel 1

Informan Penelitian

\begin{tabular}{clc}
\hline No & \multicolumn{1}{c}{ Informan } & Jumlah \\
\hline $\mathbf{1}$ & Lurah Cipadung Kulon (Suhenda) & 1 \\
$\mathbf{2}$ & Kasi Kesejahteraan Sosial (Anita Mulyati) & 1 \\
$\mathbf{3}$ & Garda Tahun 2017 (Rohman) & 1 \\
$\mathbf{4}$ & Pemilik Agen (Yani) & 1 \\
$\mathbf{5}$ & Penerima Manfaat (Tini, Anah, Heni Handayani, Idah Karsidah, & 5 \\
Jumlah & Dede Rosita) & 9 \\
\hline
\end{tabular}

Sumber: Hasil Penelitian (diolah peneliti), 2019.

\section{HASIL PENELITIAN DAN PEMBAHASAN}

Peneliti secara berurutan akan membahas empat dimensi yang menjadi fokus bahasan yakni dimensi: (a) Komunikasi; (b) Sumber daya; (c) Disposisi; dan (d) Struktur Birokrasi.

\section{Dimensi Komunikasi}

Komunikasi berjalan dengan baik, manakala pesan yang disampaikan komunikator dapat dipahami oleh penerima pesan (komunikan), sehinga prosesnya melalui transmisi, kejelasan, dan konsistensi, yang berikut ini akan dijelaskan:

- Transmisi

Dalam praktik sering timbul hambatan dalam mentransmisikan (menyalurkan) perintah implementasi disebabkan: (1) Perbedaan pendapat antara pelaksana dengan perintah yang dikeluarkan pengambil kebijakan; (2) Struktur birokrasi yang ketat dan hierarkis cenderung mendistorsikan informasi; (3) Persepsi yang selektif dan ketidakpatuhan para pelaksana memenuhi berbagai persyaratan kebijakan, sehingga dimungkinkan untuk melakukan etnografi komunikasi yang menghasilkan setidaknya dua model komunikasi. Karena model yang muncul didasarkan pada persamaan ataupun perbedaan peran, kepentingan, tujuan serta upaya yang dilakukan (Widodo, 2019).

Terkait indikator yang harus diketahui oleh pelaksana, seorang informan menjelaskan: "Kalau memberikan pemahaman kepada masyarakat mengenai program BPNT, biasanya nama-nama KPM, nama-nama penerima manfaatnya itu sudah ada dari pusat namanya udah ada daftardaftarnya, jadi kita langsung menerima nama KPM nya. Nah udah gitu biasanya kita memanggil nama-nama KPM nya, rapat lah istilahnya mah dipanggil, diberitahukan bahwa nama-nama tersebut itu mendapatkan BPNT atau beras gitu. Setelah itu disosialisasikan dapatnya berapa, terus pembagiannya dari tanggal berapa, ya disosialisasikan aja langsung ke warganya di undang gitu seperti itu" (Anita Mulyati hari Selasa, 19 Maret 2019 Pukul 11:07 di Kantor Kelurahan Cipadung Kulon).

Dari pernyataan tersebut, maka dapat dilihat bahwa pada pelaksanaannya proses penyampaian informasi kebijakan dilakukan secara langsung kepada masyarakat sebelum pencanangan kebijakan. Seperti yang diungkapkan informan lain: 
"Pernah, di Kecamatan" (Tini, hari Sabtu, 16 Maret 2019 Pukul 08:49 di rumahnya). Hal ini sependapat dengan informan:

"Pernah, pas awal-awal cuma sekali belum pernah ada lagi" (Anah, Jum'at, 15 Maret 2019 Pukul 17:07 di rumahnya). Hal lain sependapat dengan informan:

"Pernah sakali sabari mere kartu beureum (pernah sekali sekaligus memberikan kartu merah) di kecamatan, belum pernah ke rumah mah" (Heni Handayani, Sabtu, 16 Maret 2019 Pukul 09:18 di rumahnya).

Dari informasi yang diberikan oleh Bapak Henda dan Ibu Anita, ternyata tidak semuanya benar, karena masih ada masyarakat yang belum benar-benar mengetahui mengenai program BPNT, berikut hasil wawancara:

"Kurang paham, awalnya kan tidak pakai kartu sekarang pakai kartu, Ibu gak ngerti cara pakainya apalagi Ibu udah tua suka lupa password-nya, jadi suka ditukar sama suami Ibu aja ke agennya" (Tini, Sabtu, 16 Maret 2019 Pukul 08:49 di rumahnya).

Berdasarkan wawancara di atas penulis dapat menyimpulkan bahwa proses sosialisasi dalam program BPNT yang dilakukan oleh para implementer belum optimal, karena masih ada masyarakat penerima bantuan yang belum mengerti mengenai mekanisme penggunaan kartu elektronik sebagai alat tukar bahan pangan. Hal tersebut dikarenakan proses sosialisasi hanya dilakukan satu kali saja itupun sebelum proses penyaluran program tersebut.

\section{Kejelasan}

Komunikasi harus jelas dan dimengerti para pelaksana, yang menyangkut kejelasan petunjuk pelaksana maupun kejelasan pesan komunikasi yang disampaikan. Hal ini penting agar kebijakan-kebijakan yang diimplementasikan dapat mencapai sasaran yang dikehendaki. Ketidakjelasan petunjuk pelaksana maupun pesan komunikasi yang disampaikan akan menimbulkan interpretasi yang keliru bahkan mungkin bertentangan dengan makna sesungguhnya dari petunjuk dan pesan komunikasi yang pada gilirannya menimbulkan penyimpangan yang fatal dalam implementasi di lapangan.

Berdasarkan jawaban dalam wawancara dengan Lurah Cipadung Kulon (Suhenda) terkait dengan komunikasi yang dilakukan untuk melaksanakan kebijakan program BPNT diperoleh hasil sebagai berikut: "Sudah, kita sosialisasikan tugas-tugas pokoknya, tugasnya apa aja sih yang harus didata, sudah tahu. Jadi petugas sebelum ke lapangan itu sudah memahami tugas masingmasing" (Suhenda, Senin, 18 Maret 2019 Pukul 13:26 di Kantor Kelurahan Cipadung Kulon).

Demikian juga disampaikan Kasi Kesejahteraan Sosial Cipadung Kulon: "Iya, iya udah jelas, jadi adanya program BPNT digulirkan ke masyarakat, pencairan lah ibaratnya gitu, kita di undang dulu sama pihak terkaitnya, kalau dulu kan dinas pertanian kalau sekarang dinas sosial. Jadi kita diundang dulu ya para camat, lurah, di undang dulu misalnya kita akan ada program BPNT, misalnya per kecamatan atau per kelurahan itu udah diberitahukan KPM-nya berapa-berapa nya, tiap kelurahan kan berbeda yah seperti itu, nanti teknis pelaksanaannya bagaimana-bagaimana kita diundang rapat dulu" (Anita Mulyati, Selasa, 19 Maret 2019 Pukul 11:07 di Kantor Kelurahan Cipadung Kulon).

Berdasarkan wawancara di atas, dalam aspek kejelasan informasi mengenai tugas para pelaksana sudah disampaikan secara jelas oleh pihak pusat. Selain itu pemerintah juga telah menyampaikan dengan jelas maksud dan tujuan dari pelaksanaan tersebut, yakni memberantas kemiskinan dengan mengurangi beban masyarakat dalam pemenuhan kebutuhan pokok.

\section{Konsistensi dalam Mengomunikasikan Kebijakan}

Hal ini menyangkut kepastian dan kejelasan perintah yang harus dilaksanakan oleh para pelaksana. Artinya perintahperintah yang diterima oleh pelaksana tidak boleh bertentangan satu sama lain, sehingga tidak membingungkan pelaksana (perintah tidak boleh berubah-ubah). Tidak konsistensinya perintah dapat mendorong para pelaksana mengambil tindakan yang 
bertentangan dengan maksud sesungguhnya dari suatu implementasi kebijakan.

Berdasarkan jawaban dalam wawancara dengan Lurah Cipadung Kulon, terkait dengan konsistensi perintah yang dilakukan untuk melaksanakan kebijakan program BPNT diperoleh hasil sebagai berikut: "Konsisten, kita kan hanya menjalankan perintah dari pusat. Data kan dari pusat dari Dinas Sosial itu tetap, kami tidak bisa mengeluarkan karena datanya tahun 2005. Kemarin kan warganya miskin ada perbaikan peningkatan ekonomi sekarang menjadi mampu, tapi data-data ini tidak bisa dihapus begitu saja harus ada dari yang bersangkutan untuk mengundurkan diri atau mencoret bisa, kalau kami untuk mencoret itu tidak bisa. Jadi yang bersangkutan sudah tidak layak lagi menerima ini, nah ini bisa kami coret cuma harus ada surat pernyataan dari yang bersangkutan. Penggantinya diusulkan lagi tapi datanya dari RW siapa-siapa nya yang layak, jadi menunggu tidak langsung ini coret ini masuk tidak bisa" (Suhenda, Senin, 18 Maret 2019 Pukul 13:26 di Kantor Kelurahan Cipadung Kulon).

Berdasarkan kutipan wawancara di atas, dapat diketahui bahwa konsistensi dan penyampaian informasi terkait dengan kebijakan program Bantuan Pangan Nontunai sudah berjalan dengan konsisten sesuai dengan data dan aturan dari pusat. Sehingga dapat disimpulkan, komunikasi yang terjalin antara para pelaksana dengan masyarakat penerima dalam implementasi kebijakan program BPNT ini telah terjalin dengan baik meskipun masih ada masyarakat yang masih belum mengerti atau memahami mekanisme dari program tersebut.

Sesungguhnya suatu penegakan kebijakan tidak mungkin terwujud dalam masyarakat jika para pelaksana kebijakan tidak memainkan perannya dengan maksimal sebagai penegak kebijakan. Semakin baik saluran komunikasi tersedia akan semakin tinggi probabilitas kebijakan itu dipahami oleh para pelaksana.

\section{Dimensi Sumber Daya}

Dimensi ini merupakan salah satu faktor yang mendukung sebuah kebijakan. Ketersediaan sumber daya dalam sebuah implementasi kebijakan memberikan pengaruh yang besar terhadap keberhasilan sebuah implementasi kebijakan. Sumber daya dalam implementasi kebijakan program bantuan pangan nontunai sebagai bentuk dari pemenuhan kebutuhan pokok rumah tangga meliputi sumber daya manusia (staf), wewenang, informasi, dan fasilitas-fasilitas yang diperlukan guna melaksanakan pelayanan-pelayanan publik yang dapat dijelaskan berikut:

\section{Staf}

Manusia merupakan faktor sentral dalam suatu organisasi, instansi atau lembaga. Tanpa sumber daya yang memadai, tentu implementasi tidak akan berjalan optimal. Dalam menjalankan suatu kebijakan diperlukannya sumber daya aparat yang berkualitas, karena para pelaksana kebijakan harus mengetahui serta memahami apa yang akan dikerjakan atau apa yang akan menjadi tugas mereka sesuai dengan kedudukan dan keahlian mereka.

Berikut hasil wawancara dengan Lurah Cipadung Kulon: "Alhamdulillah, staf kami ada 6 (enam). Alhamdulillah kami kerjasama jadi tidak ada tugas Kesos kasih ke yang lain tidak. Kalau sibuk dibantu jadi muter kami diarahkan semuanya seperti itu, para pelaksanapun seperti itu jadi tidak ada masalah kalau kata orang Sunda mah pa aingaing tidak, walaupun memang tidak sesuai tupoksinya tapi harus membantu" (Suhenda, Senin, 18 Maret 2019 Pukul 13:26 di Kantor Kelurahan Cipadung Kulon).

Hal ini sependapat dengan Kasi Kesejahteraan Sosial: "Alhamdullilah baik, sekarang udah berjalan dengan lancar jadi tiap bulan ke bulan udah makin ada peningkatan" (Anita Mulyati, Selasa, 19 Maret 2019 Pukul 11:07 di Kantor Kelurahan Cipadung Kulon).

Berdasarkan hasil wawancara yang dilakukan oleh peneliti, SDM yang dikerahkan dalam implementasi kebijakan ini dapat dikatakan sudah memadai karena setiap bulannya sudah mengalami peningkatan, SDM di sini bukan hanya staf saja tapi ada yang dinamakan Garda. Tahun 2017 setiap rukun warga memiliki satu Garda, namun di tahun 2018 mengalami filterisasi bahwa yang 
menjadi Garda harus berpendidikan minimal Sekolah Menengah Atas (SMA), sehingga di tahun 2018 di Kelurahan Cipadung Kulon hanya memiliki tiga Garda dari yang awalnya sebelas Garda. Hal ini membuat para Garda yang baru kewalahan dengan penerima bantuan yang begitu banyak hanya ditangani oleh tiga orang saja.

\section{Wewenang Aparat dalam Menjalankan Kebijakan}

Ini menyangkut besaran jangkauan tugas yang dapat dilakukan oleh pejabat pembuat kebijakan maupun para pelaksana. Oleh karena itu wewenang ini akan berbedabeda dari satu program ke program lainnya.

Seseorang dapat saja memiliki wewenang yang luas tetapi tidak cukup efektif dalam mengimplementasikan suatu kebijakan. Mengingat terbatasnya wewenang, maka perlu kerjasama antara para pejabat maupun pelaksana di lapangan. Wewenang hadir dalam berbagai wajah, dari penyediaan fasilitas, memberi bantuan, sampai memaksakan perilaku. Kewenangan ini harus bersifat formal karena merupakan otoritas atau legitimasi untuk melaksankan tugas.

"Kalau wewenang khusus tidak, sudah ditentukan dari pusat, kalau kami yang mengeluarkan wewenang kami yang kena, kami tidak bisa merubah kita cuma mengusulkan" (Suhenda, Senin, 18 Maret 2019 Pukul 13:26 di Kantor Kelurahan Cipadung Kulon).

Adapun jawaban lain Kasi Kesejahteraan Sosial: "Paling kalau kita sih hanya memantau saja memonitoring" (Anita Mulyati, Selasa, 19 Maret 2019 Pukul 11:07 di Kantor Kelurahan Cipadung Kulon).

Dari hasil wawancara tersebut dapat disimpulkan bahwa para implementer sudah menjalankan tugas sesuai dengan wewenang yang telah diperintahkan pusat, dan tidak dapat mengeluarkan wewenang lain. Hal ini dapat mempermudah para pelaksana mencapai tujuan kebijakan program.

\section{Aspek Informasi}

Aspek ini adalah hal penting lainnya dalam implementasi suatu kebijakan. Informasi mempunyai dua bentuk: Pertama, informasi tentang bagaimana melaksanakan suatu kebijakan. Artinya para pelaksana perlu mengetahui apa yang harus dilakukan dan bagaimana mereka harus melakukannya. Kedua, data tentang ketaatan para pelaksana terhadap peraturan pemerintah. Kedua bentuk informasi tersebut penting bagi efisiensi dan keunggulan para pelaksana dalam melaksanakan tugas masing-masing.

"Informasi itu kan penting, sekecil apapun informasi harus disampaikan ke petugas nanti kan seperti yang sudah disampaikan nanti petugas ke lapangan kan udah enak. Jadi ke lapangan itu dia sudah tidak canggung lagi punya dasarnya, punya aturan nya, jadi enak dan petugas masingmasing RW koordinasi, jadi langsung berhubungan mau ada kendala atau tidak harus ada laporan" (Suhenda, Senin, 18 Maret 2019 Pukul 13:26 di Kantor Kelurahan Cipadung Kulon).

Hal lain dikemukakan oleh Garda tahun 2017: "Itu kurang tahu, memang ada kasus kartu punya BPNT ada, PKH ada tetapi ketika di cek saldo itu tidak ada, di RW 02 juga banyak kasus. Pernah tahun 2017 kita berupaya kebetulan ada musyawarah, ya alhamdulillah ada penambahan penerima, ya setelah itu upaya-upaya diupayakan tidak ada lagi” (Rohman, Sabtu, 6 April 2019 pukul 08:31, di rumahnya).

Berdasarkan wawancara di atas, disimpulkan bahwa informasi yang ada di lapangan tidak disampaikan secara jelas kepada para kelompok sasaran (masyarakat penerima bantuan) yang mengalami beberapa kendala.

Selain informasi tentang melaksanakan suatu kebijakan yang berarti para implementer mengetahui apa yang harus mereka lakukan ada juga data ketaatan para pelaksana terhadap aturan pemerintah. Berikut jawaban wawancara yang dipaparkan oleh Lurah Cipadung Kulon: "Enggak, mau tidak mau harus dilaksanakan gak bisa menolak, kalau yang menolak berarti mengundurkan diri pindah begitu. Untuk kebersamaan sih mau tidak mau kita harus membantu tupoksinya staf ini" (Suhenda, Senin, 18 Maret 2019 Pukul 13:26 di Kantor Kelurahan Cipadung Kulon).

Dari hasil wawancara peneliti dapat memahami bahwa tidak hanya informasi 
antar pelaksana yang berpengaruh terhadap jalannya suatu kebijakan tetapi juga sikap aparatur yang harus mempunyai integritas tinggi terhadap tanggung jawabnya (ketaatan para pelaksana terhadap peraturan pemerintah) sebagai pelayan publik, sehingga apa yang menjadi tujuan dari kebijakan tersebut bisa tercapai.

\section{Fasilitas-Fasilitas Penunjang Operasional Kebijakan}

Dimaksudkan di sini menyangkut ketersediaan sarana fisik. Seorang kepala dinas mungkin saja memiliki staf yang memadai, memahami apa dan bagaimana harus melakukan sesuatu dengan dilengkapi berbagai kewenangan tapi tanpa kantor dan perlengkapan lainnya, maka besar kemungkinan akan mengalami kegagalan dalam mengimplementasikan kebijakan yang telah dibuat oleh dinas bersangkutan.

Berikut hasil wawancara dengan Lurah Cipadung Kulon: "Kalau sarana dan prasarana kan kami cuma yang ada di kelurahan, ya prasarana sih bagaimana kebijakan Lurah. Contohnya itu untuk ke lapangan kan Sikemas gak punya kendaraan, sarananya yang penting di kelurahan ada kendaraan coba pakai yang ada. Jangan sampai mau ke lapangan gak ada kendaraan" (Suhenda, Senin, 18 Maret 2019 Pukul 13:26 di Kantor Kelurahan Cipadung Kulon).

Jawaban lain dikemukakan oleh Kasi Kesejahteraan Sosial: "Alhamdulillah sekarang memadai, jadi kita di sini di Cipadung Kulon kita sudah punya agen sekarang. Asalnya kita ikut ke kelurahan lain, karena mungkin belum adanya fasilitas dari kitanya. Kalau dulu harus E-Warong tapi sih warung-warung memang banyak, tapi belum menunjang, tapi Alhamdulillah kita sudah punya agen" (Anita Mulyati, Selasa, 19 Maret 2019 Pukul 11:07 di Kantor Kelurahan Cipadung Kulon).

Berikut hasil wawancara dengan pemilik agen di Cipadung Kulon: "Ibu mulai bulan Juli 2018, sebenarnya ibu gak ingin sih (menjadi agen), cuma teman-teman, rekanrekan Garda mengajukan ibu jadi agen, soalnya di Cipadung Kulon gak ada yang memiliki warung" (Yani, Jum'at, 15 Maret 2019 Pukul 15:48 di rumahnya).
Berdasarkan hasil observasi dan wawancara tersebut, dapat ditarik simpulan bahwa fasilitas penunjang operasional kebijakan program BPPT belum cukup memadai, karena pada awal penyaluran ada keterlambatan fasilitas agen tempat penukar bahan pangan yang membuat para penerima harus menempuh jarak jauh untuk menukarkan bahan pangan (di Kelurahan Mekar Mulya). Namun sekarang Cipadung Kulon sudah memiliki agen yang bertempat di Jalan Sindangsari IV. Selain itu kurangnya transportasi sehingga menghambat Kasi Kesejahteraan Sosial untuk mengontrol ke lapangan, dan mesin EDC sering error.

\section{Dimensi Disposisi}

Sikap dari pelaksana kebijakan adalah faktor penting dalam suatu pelaksanaan kebijakan publik. Jika para pelaksana baik karena menerima suatu kebijakan, kemungkinan besar mereka akan melaksanakan kebijakan tersebut secara bersungguh-sungguh seperti yang diharapkan pembuat kebijakan Sebaliknya, jika perspektif dan tingkah laku para pelaksana berbeda dengan para pembuat kebijakan, maka proses implementasi kebijakan akan mengalami kesulitan.

Disposisi juga menyangkut persepsi, kewenangan, pemahaman dan komitmen para pelaksana untuk menetapkan suatu kebijakan. Terdapat tiga kemungkinan sikap dari disposisi yaitu menerima, menolak, atau bersikap netral. Agar implementasi kebijakan berjalan efektif, maka segenap upaya harus dilakukan oleh pembuat kebijakan agar isi dan tujuan kebijakan dapat berkesesuaian dengan keinginan para implementer melalui pemahaman setiap individu akan arah kebijakan yang mereka kerjakan/ implementasikan. Di samping itu para pelaksana harus memahami/mengetahui apa yang harus dikerjakan, mereka juga harus memiliki kemampuan untuk melaksanakannya.

\section{Sikap Aparat}

Dalam menjalankan kebijakan, dalam mengimplementasikan program ini tentunya mengalami berbagai kendala. Berikut hasil wawancara dengan Lurah Cipadung Kulon: 
"Kalau keluhan memang banyak, seperti yang tadi disampaikan ada warga yang betul-betul membutuhkan tidak mendapatkan, Sikemas menyampaikan ke kami coba masukan dulu, harus dirapatkan dari mulai RW siapa-siapa saja yang betul-betul membutuhkan untuk diajukan ke kota, lalu kami usulkan jadi ada rapat $\mathrm{RW}$, siapa saja si a si b yang harus masuk, RW lebih tahu mana warga yang kurang mampu, kami didasarkan pada data RW" (Suhenda, Senin, 18 Maret 2019 Pukul 13:26 di Kantor Kelurahan Cipadung Kulon).

Pendapat berikutnya disampaikan oleh Kasi Kesejahteraan Sosial: "Biasanya kita tampung dulu ya keluhan-keluhan, kita kan kalau BNPT gitu kan ada ini nya...jadi ada apa sih...kalau misalnya sama TKSK, sama ada yang dinas terkaitnya, terus sama banknya gitu. Kalau ada masalah-masalah gitu kita pasti cepat adakan rapat untuk membicarakan keluhan-keluhan ini" (Anita Mulyati, Selasa, 19 Maret 2019 Pukul 11:07 di Kantor Kelurahan Cipadung Kulon).

Peneliti selanjutnya menanyakan mengenai keluhan masyarakat yang merasa bahwa bantuan ini belum tepat sasaran serta masih ada masyarakat yang terdata namun hanya mendapat satu kali saja. Berikut wawancara dengan masyarakat penerima bantuan: "Sebenarnya tidak ada kendala, orang saya cuma dapet sekali aja itupun berasnya jelek gak layak buat dimakan untuk manusia, saya pernah nyoba ngecek lagi berharap dapat lagi gitu, ternyata pas dicek saldonya cuma ada Rp12.000,00 akhirnya mah dituker dengan kecap" (Idah Karsidah, Sabtu, 16 Maret 2019 Pukul 09:03 di rumahnya).

Keluhan lain disampaikan oleh masyarakat penerima bantuan: "Kartu milik saya hilang, ada juga kartu yang beda, kartu untuk mengambil uang (PHK), jadi tidak bisa mengambil beras, dikira cukup dengan satu kartu. Jadi tidak dapat bagian lagi (setelah katu hilang tidak mendapatkan program BNPT lagi), pernah mengajukan ke bank penyalur tiga kali kalau tidak salah, tapi kata petugas bank harus diurus lagi kartunya ke pengurus di kelurahan" (Dede Rosita, Sabtu, 16 Maret 2019 Pukul 09:12 di rumahnya).

Hal lain yang disampaikan oleh masyarakat penerima bantuan: "Baru kali ini sih ada kendala mah, bulan kemarin sama bulan ini gak dapat (Februari dan Maret) padahal biasanya suka dapat tiap bulan juga" (Heni Handayani, Sabtu, 16 Maret 2019 Pukul 09:18 di rumahnya).

Ketika ditanyakan mengenai keluhan ini Kasi Kesejahteraan Sosial, berikut alasannya: "Iya sih sebetulnya kita juga tidak mengerti kan kasian mereka yang hanya menerima satu tahun hanya sekali, terus penerima tiap bulan datang kesini, kok saya tidak menerima kenapa, sedangkan tetangga saya tiap bulan dalam keadaan cukup, selalu mendapatkannya, sebenarnya sih kita juga ya kenapa sampai seperti itu kan kasian ya, cuma kan jadi apa...nama daftar KPM itu begitu atau penyalurannya itu biasanya per tahun atau per bulan langsung ada datang dari pusatnya, jadi kita gak oh bulan ini si ibu a b c bulan depan si a nya kadang ada b c nya gak ada, terus kadang yang bulan kapan ada gitu, kita lihat tiap bulan itu, oh yang ini dapat oh iya yang ini tidak kita lihat, memang kita juga suka komplain sama TKSK atau pedampingnya tolong dong tanyain ke banknya, atau gimana kok gak dapat lagi sampai nama-namanya sudah didaftarkan, dikasihkan ke banknya tapi sampai saat ini belum ada jawaban malah nanti saja mudahmudahan paling seperti itu jawabannya." (Anita Mulyati, Selasa, 19 Maret 2019 Pukul 11:07 di Kantor Kelurahan Cipadung Kulon).

Pendapat dari Garda tahun 2017 yang menanggapi keluhan-keluhan dari masyarakat penerima bantuan: "Bisa iya bisa tidak, pernah ada kasusnya, kenapa disebut belum tepat sasaran, karena memang masih ada keluarga yang sangat membutuhkan tapi tidak tersentuh oleh baik ke BPNT ataupun PKH bahkan di basis data terpadu juga tidak ada. Kalau untuk saling menyalahkan kan gampang kita menyalahkan orang yang mengolah, tapi dari sana juga pasti menyalahkan kita, ya dapat informasi dari mana kalau bukan dari bawah. Sementara pernah ada setiap enam bulan kita selalu ada pembaruan data ngasih, mengajukan, ini yang sudah dapat ini yang belum, ternyata yang keluar itu juga" (Rohman, Sabtu, 6 April pukul 08:31 di rumahnya).

Berdasarkan hasil wawancara di atas peneliti dapat menarik simpulan, bahwa sikap 
para aparatur Kelurahan Cipadung Kulon kurang dalam merespon keluhan-keluhan masyarakat. Seolah-olah aparatur pelaksana kebijakan belum memahami secara menyeluruh penyebab dari permasalahanpermasalahan yang terjadi.

\section{Insentif}

Pada umumnya orang bertindak menurut kepentingan mereka sendiri, maka diperlukan manipulasi insentif agar orang dapat bertindak seuai harapan pembuat kebijakan yaitu dengan cara menambah keuntungan atau biaya tertentu sehingga mendorong para pelaksana melaksanakan perintah dengan baik. Berikut jawaban dari Lurah Cipadung Kulon: "Alhamdulillah, kebetulan kalau di kami petugas tidak melihat besar kecilnya yang penting tugas dulu selesai, apa nanti ada imbalan honor dari dinas terkait itu haknya, jadi tidak melihat dari honornya yang penting tugas. Biasanya gak tiap bulan paling tiga bulan sekali” (Suhenda, Senin, 18 Maret 2019 Pukul 13:26 di Kantor Kelurahan Cipadung Kulon).

Berdasarkan jawaban wawancara di atas, maka dapat diketahui bahwa para aparat tidak selalu mengharapkan insentif yang paling penting ialah tugas masing-masing selesai. Namun, terkait dengan insentif yang diberikan kepada para pelaksana kebijakan setiap tiga bulan sekali itu ialah berupa tunjangan kinerja pegawai. Tunjangan kinerja tersebut menjadi sesuatu yang dapat memicu semangat para pegawai dalam menjalankan tugas dan fungsinya selaku aparatur pelaksana kebijakan.

\section{Dimensi Struktur Birokrasi}

Menurut Edward III dalam Pasolong (2013) yang memengaruhi tingkat keberhasilan implementasi kebijakan adalah struktur birokrasi. Walaupun sumber dayasumber daya untuk melaksanakan suatu kebijakan tersedia, atau para pelaksana kebijakan mengetahui apa yang seharusnya dilakukan, dan mempunyai keinginan untuk melaksanakan suatu kebijakan, kemungkinan kebijakan tersebut tidak dapat terlaksana atau terealisasi karena terdapat kelemahan dalam struktur birokrasi.
Kebijakan yang begitu kompleks menuntut adanya kerjasama banyak orang, ketika struktur birokrasi tidak kondusif pada kebijakan yang tersedia. Maka hal ini akan menyebabkan sumber daya - sumber daya yang ada menjadi tidak efektif dan tidak termotivasi sehingga menghambat jalannya kebijakan. Birokrasi sebagai pelaksana sebuah kebijakan harus dapat mendukung kebijakan yang telah diputuskan secara politik dengan jalan melakukan koordinasi dengan baik. Berikut hasil wawancara dengan Lurah Cipadung Kulon: "Sudah ditentukan dari pusat, mau tidak mau harus dilaksanakan, gak bisa menolak kalau yang menolak berarti mengundurkan diri pindah gitu. Untuk kebersamaan sih mau tidak mau kita harus membantu tugas pokok dan fungsi (tupoksi) staf' (Suhenda, Senin, 18 Maret 2019 Pukul 13:26 di Kantor Kelurahan Cipadung Kulon).

Berdasarkan hasil wawancara dengan Bapak Suhenda terkait mekanisme pembagian wewenang di Kelurahan Cipadung Kulon Kecamatan Panyileukan Kota Bandung diperoleh keterangan-keterangan bahwa para pelaksana kebijakan di Kelurahan Cipadung Kulon sudah mengetahui tugas dan fungsi mereka, serta sudah sesuai dengan pembagian wewenang mereka masing-masing.

\section{Faktor Penghambat dan Pendukung Pelaksanaan Kebijakan Program Bantuan Pangan Nontunai di Kelurahan Cipadung Kulon}

\section{- Faktor Penghambat}

Merupakan suatu kendala dalam menjalankan kebijakan, karena faktor penghambat ini membuat pelaksanaan kebijakan tidak berjalan dengan semestinya, sehingga dapat memberikan dampak yang negatif terhadap jalannya birokrasi dan pelayanan publik. Berikut hasil wawancara dengan Lurah Cipadung Kulon: "Penghambatnya dari BPNT itu, pendistribusian beras, kualitas beras, dari prasarana kemarin-kemarin mah ikut ke kelurahan lain sekarang sudah mempunyai tempat sendiri (agen penukaran bahan pangan), kualitas berasnya bagaimana kalau kualitasnya kurang ya kami kembalikan lagi ke pihak Bulog melalui bank, masa untuk keluarga yang kurang mampu dikasih beras 
yang jelek" (Suhenda, Senin, 18 Maret 2019 Pukul 13:26 di Kantor Kelurahan Cipadung Kulon).

Hal lain dikemukakan Kasi Kesejahteraan Sosial: "Paling kalau suplai beras Alhamdulillah lancar, paling dari mesin terus kemarin juga katanya ada masalah, lah begitu ya mereka dengan bank" (Anita Mulyati, Selasa, 19 Maret 2019 Pukul 11:07 di Kantor Kelurahan Cipadung Kulon).

Hasil wawancara kepada $E$ Warong/pemilik agen di Kelurahan Cipadung Kulon: "Bukan keterlambatan, ini BNI katanya ada kelebihan saldo di agen jadi yang kelebihan itu rekening diblokir sebagian (rekening agen), sebenarnya kalau kehilangan saldo sih itu kan yang tahun 2017 itu cuma sekali dapat, kata BNI kalau tidak ada 2019 awal saldonya muncul, itu sebagian dialihkan ke $\mathrm{PKH}$, penghambatnya paling kalau beras lagi jelek, terus terlambat pemasukan saldo dari BNI" (Yani, Jum'at, 15 Maret 2019 Pukul 15:48 di rumahnya).

Hambatan lain dikemukakan Garda tahun 2017 mengenai keterlambatan kartu KKS KPM: "Sebetulnya itu tidak mungkin, ini kan diambilnya dari Basis Data Terpadu, kenapa dia tidak dapat kartu, karena tidak sinkronnya data, tidak banyak dari warga yang tidak memperhatikan pentingnya Kartu Keluarga. Contoh: di dalam Kartu Keluarga mempunyai lima anak yang satu sudah menikah namun belum dibuatkan KK yang baru. itu bisa menjadi masalah, itu bukan kesalahan dari yang mengolah data, balik lagi ke warganya sudahkah memperhatikan pentingnya KTP, masalah KK soalnya semua informasi ada di nomor NIK-nya itu" (Rohman, Sabtu, 6 April 2019, Pukul 08:31 di rumahnya).

Berdasarkan hasil wawancara di atas bahwa faktor penghambat dalam pelaksanaan Program BPNT tersebut dipengaruhi oleh kewenangan di dinas-dinas terkait dalam pelaksanaan kebijakan program tersebut, karena untuk pengendalian kebijakan tersebut wewenangnya berada di Dinas Sosial dan pihak bank, sehingga ketika para aparat kelurahan Cipadung Kulon ingin mengambil tindakan untuk pengendalian keluhan-keluhan masyarakat mengenai program ini mereka tidak bisa melakukan hal itu karena bukan kewenangan mereka, karena aparat di Kelurahan Cipadung Kulon hanya memonitoring atau mengawasi saja, agar tepat sasaran, keterlambatan kartu KKS para KPM, saldo penerima nol yang seharusnya terisi Rp110.000,00 per bulan, dan sering terjadi keterlambatan pendistribusian beras.

\section{- Faktor Pendukung}

Keberhasilan dalam pelaksanaan kebijakan pasti dipengaruhi oleh faktor-faktor pendukung, berikut faktor-faktor pendukung yang dijelaskan Lurah Cipadung Kulon: "Kerjasama dengan staf, Alhamdulillah, kami selalu bersama-sama kasih masukan, bantu membantu seperti Kasi yang bersangkutan dibantu oleh IT dalam mengerjakan laporanlaporan, terus dari pertugas lapangan juga selalu kontak" (Suhenda, Senin, 18 Maret 2019 Pukul 13:26 di Kantor Kelurahan Cipadung Kulon).

Berdasarkan hasil wawancara di atas, bahwa faktor pendukung dari program BPNT ini adalah kerjasama staf yang saling membantu walaupun bukan tupoksinya, selain itu penulis melihat bahwa sarana prasarana seperti memiliki E-Warong sendiri menjadi faktor pendukung dalam implementasi program ini walaupun memang baru terlaksana di pertengahan tahun 2018 .

\section{Harapan Masyarakat untuk Program BPNT}

Pemerintah sangat serius dalam memerangi kemiskinan dan ketimpangan. Hal ini diwujudkan dengan meningkatkan anggaran bantuan sosial maupun perluasan target sasaran.

"Salah satu program bantuan sosial yang berkontribusi terhadap penurunan angka kemiskinan adalah Program Keluarga Harapan (PKH) yang terintegrasi dengan program Bantuan Pangan Nontunai (BPNT) atau Rastra", terang Menteri Perindustrian Airlangga Hartato (Hartato, 2019).

Dengan bantuan PKH dan BPNT, KPM bisa membeli kebutuhan pokok pangan yang berkualitas baik dan kebutuhan sekolah anak dengan harga yang murah, sehingga kesehatan dan gizi keluarga lebih terjaga. KPM juga dapat membeli kebutuhan sekolah anak sehingga pendidikan anak lebih 
terperhatikan. Yang terpenting, anak tumbuh sehat dan terhindar dari gizi buruk atau stunting, imbuh Airlangga Hartato.

Pada kenyataannya program BNPT ini dirasa belum cukup memenuhi kebutuhan pokok rumah tangga. Berikut hasil wawancara dengan penerima bantuan mengenai harapan ke depannya: "Kirang 10 kilo mah, harapanna mah hoyong keging deui we, hoyong dilebihkeun, dicekapkeun sasasiheun entong 10 kilo teuing." (Dede Rosita, Sabtu, 16 Maret 2019 Pukul 09:12 di rumahnya).

Hal lain diungkapkan oleh penerima bantuan: "Gak cukup memenuhi kebutuhan pokok sedikit hanya 9 kilo. Seharusnya berasnya yang bagus, dapat PKH juga biar sekalian sama beras begitu, tambahan gula pasir, telor seperti itu" (Heni Handayani, Sabtu, 16 Maret 2019 Pukul 09:18 di rumahnya).

Begitu juga pendapat penerima bantuan lainnya: "Harapannya mau mendapatkan lagi, kalau tidak bisa, tidak apa-apa" (Idah Karsidah, Sabtu, 16 Maret 2019 Pukul 09:03 di rumahnya).

Berikut harapan yang dikemukakan pemilik agen di Kelurahan Cipadung Kulon: "Harapan ibu mah penyaluran tepat waktu, terus berasnya bagus, EDC tidak error, itu saja" (Yani, Jum'at, 15 Maret 2019 Pukul 15:48 di rumahnya).

Berdasarkan uraian di atas bahwa pelaksanaan BPNT ini sangat memberikan kontribusi terhadap penurunan angka kemiskinan. Pertengahan Januari 2019, Badan Pusat Statistik (BPS) merilis bahwa angka kemiskinan di Indonesia kembali turun dari 9,82 persen ke 9,66 persen. Namun, masih ada kendala-kendala yang terjadi yang membuat sebagian masyarakat berpandangan bahwa program ini belum berjalan sesuai dengan harapan masyarakat (Badan Pusat Statistik, 2019). Dengan demikian komunkasi kebijakan sejatinya harus dilaksanakan penanggulangannya secara komprehensif dan berkesinambungan dengan melibatkan berbagai mitra terkait (Engkus E \& Hikmat Saminnurahmat, 2017).

\section{PENUTUP}

\section{Simpulan}

Komunikasi kebijakan BPNT ini sudah terlaksana, namun belum optimal. Dimensi komunikasi, proses komunikasi pemerintah pusat dan kelurahan masih belum lancar, berakibat lemahnya peran dan fungsi kelurahan sebagai garda terdepan. Dimensi sumber daya masih selalu tergantung ke pemerintah pusat dalam segala tindakannya, sehingga komunikasi KPM dengan pemberi manfaat (pemerintah pusat/Kemensos) tidak jelas. Artinya kewenangan kelurahan masih lemah. Dimensi disposisi, pemahaman perintah, komunikasi antara pemberi manfaat, dengan pihak kelurahan, KPM, penyalur bantuan masih terputus. Dimensi struktur birokrasi, belum jelas, sehingga data yang tersedia belum mutakhir, yang berakibat program tidak tepat sasaran. Hal ini terjadi karena tidak adanya petugas yang berperan menjembatani sebagai advokasi dan pengawas di tingkat lapangan.

\section{Saran}

Pemerintah pusat dan pemerintah di tingkat kelurahan seyogyanya meningkatkan desain program, komunikasi, diseminasi, dan sosialisasi mengenai program BNPT kepada masyarakat agar masyarakat lebih paham mengenai maksud dan tujuan dari BPNT itu sendiri. Peningkatan kompetensi dan kapasitas SDM aparatur agar pelaksanaannya berjalan komunikatif, efektif, dan responsif serta terintegratif terhadap kebijakan dan masyarakat.

\section{DAFTAR PUSTAKA}

Badan Pusat Statistik (2019) Angka Kemiskinan . Badan Pusat Statistik (2016) Kemiskinan dan Ketimpangan.

Engkus, E. (2018) IMPLEMENTASI UNDANGUNDANG PERDAGANGAN DAN IMPLIKASINYA DALAM PENGENDALIAN HARGA KEBUTUHAN POKOK MASYARAKAT. LITIGASI. [Online] 18 (1), 20-46. Available from: doi:10.23969/litigasi.v18i1.284.

Engkus, E. (2017) Perspektif Kebijakan Publik. Bandung, El-Markazi. 
Engkus, E., Hikmat, H. \& Saminnurahmat, K. (2017) Perilaku Narsis pada Media Sosial di Kalangan Remaja dan Upaya Penanggulangannya. Jurnal Penelitian Komunikasi. [Online] 20 (2), 121-134. Available from: doi:10.20422/jpk.v20i2.220. Hartato, A. (2019) Program Keluarga Harapan Berkontribusi Besar Turunkan Angka Kemiskinan. [Online]. 2019. Gatra.com. Available from: https://www.gatra.com/detail/news/386831Program-Keluarga-Harapan-BerkontribusiBesar-Turunkan-Angka-Kemiskinan.

Kemensos RI, K.S.R. (2018) Pedoman Umum Bantuan Pangan Non Tunai.

Kusumadewi, R. (2016) Studi Analisis Kebijakan. Bandung, CV. Pustaka Setia.

Mulyana, A. (2018) Pengertian dan Cara Kerja Mesin EDC. [Online]. 2018. Available from: https://www.infoperbankan.com/umum/peng ertian-mesin-edc.html [Accessed: 2 October 2018].

Nurati, D.E. (2016) KOMUNIKASI KEBIJAKAN PUBLIK DALAM PENGELOLAAN PEDAGANG KAKI LIMA BERBASIS PADA KEARIFAN LOKAL (Kajian Pengelolaan Pedagang Kaki Lima di Kota Surakarta). JPAP: Jurnal Penelitian Administrasi Publik. [Online] 2 (01). Available from: doi:10.30996/jpap.v2i01.701.

Pasolong, H. (2013) Teori Administrasi Publik.
Bandung, Alfabeta.

Silalahi, U. (2009) Metode Penelitian Sosial. Bandung, Refika Aditama.

Suparman, N. (2017) Kualitas Pelayanan Izin Mendirikan Bangunan (IMB) Pada Badan Pelayanan Perizinan Terpadu dan Penanaman Modal (BPPTPM) Kabupaten Cianjur Provinsi Jawa Barat. Jurnal Borneo Administrator. [Online] 13 (1), 41. Available from: doi:10.24258/jba.v13i1.274.

Syafri, W. \& Setyoko, I. (2010) Implementasi Kebijakan Publik dan Etika Profesi Pamong Praja. Bandung, Alqaprint Jatinagor.

Wahab, S.A. (2014) Analisis Kebijakan: Dari Formulasi ke Penyusunan Model-Model Implementasi Kebijakan Publik. Jakarta, Bumi Aksara.

Widodo, A. (2019) Model Komunikasi Penegak Hukum dalam Ruang Persidangan di Pengadilan Negeri Jakarta Pusat. Jurnal Penelitian Komunikasi. [Online] 22 (2), 139-154. Available from: doi:10.20422/jpk.v22i2.660.

Winarno, B. (2014) Kebijakan Publik: Teori, Proses dan Studi Kasus. Yogyakarta, CAPS.

Yusnita, M., Agustina, D. \& Anggita, W. (2018) E-Warong sebagai Salah Satu Solusi Mengentaskan Kemiskinan Masyarakat. Proceeding of Community Development. [Online] 1, 146. Available from: doi:10.30874/comdev.2017.19. 